\title{
ROZUMIENIE SŁOWNICTWA Z OCHRONY I KSZTAŁTOWANIA ŚRODOWISKA CZŁOWIEKA W DOKUMENTACH PAŃSTWOWYCH
}

\begin{abstract}
Artykuł jest kontynuacją rozważań, które sygnalizowaliśmy w artykule „Założenia dla edukacji ekologicznej czy bezpieczeństwa ekologicznego" opublikowanym w kwartalniku „Humanities and Social Science”.

Autorzy artykułu badają różne rozumienie słownictwa i pojęć związanych z ochroną i kształtowaniem środowiska człowieka w dokumentach państwowych, na przykładzie strategii bezpieczeństwa narodowego z: 2003, 2007 i 2014 roku.

Na tematy i problemy związane z szeroko rozumianą „ekologią” w dzisiejszych czasach wypowiadają się przedstawiciele różnych dziedzin nauki zarówno teoretycy jak i praktycy. To, co dla jednych badaczy jest oczywiste, dla drugich stanowi pole do polemiki. Autorzy zwracają uwagę, że współcześnie najsilniejszym źródłem edukacji nieformalnej są media. Niestety, nie można wydać pozytywnego komunikatu po opracowaniu badań ankietowych, których celem było poznanie poziomu rozróżnialności słów i pojęć używanych w dokumentach formalnych. Jako metodę badania zastosowano sondaż diagnostyczny z wykorzystaniem ankiety. Poziom wiedzy ankietowanych jest zdecydowanie za mały. Istotną kwestią jest fakt, że to za ich życia dokonała się przemiana postaw proekologicznych. Czy brali w niej udział i zauważyli zmianę? Na te pytania odpowiedzi nie zawsze są proste i jednoznaczne, ale wymagają dalszych pogłębionych i ukierunkowanych badań na innych populacjach badanych.

Artykuł wskazuje na rolę edukacji w kształtowaniu postaw i jej niezbędność we współczesnym świecie ze względu na coraz większy i negatywny wpływ antroposfery na środowisko przyrodnicze.
\end{abstract}

Słowa kluczowe: konstytucja, strategia bezpieczeństwa narodowego, ochrona środowiska, bezpieczeństwo ekologiczne, sozologia, antropopresja

\section{WPROWADZENIE}

Eksploatując planetę Ziemię, współczesny człowiek, już nie porusza się w naturalnym środowisku człowieka (tego pierwszego zostały już tylko enklawy), tylko w ,uczłowie-

${ }^{1}$ Dr Hanna Sommer, Katedra Nauk Humanistycznych, Wydział Zarządzania, Politechnika Rzeszowska, Al. Powstańców Warszawy 8, 35-959 Rzeszów; e-mail: hansom@prz.edu.pl

${ }^{2}$ Dr inż. Grzegorz Zakrzewski, Wydział Finansów i Zarządzania, Wyższa Szkoła Bankowa w Gdańsku, Al. Grunwaldzka 238, 80-266 Gdańsk; e-mail: gzakrzewski@ @sb.gda.pl 
czonym" środowisku (środowisku antropopresji), w którym to dokonuje procesów ochrony i kształtowania wykorzystując najbardziej zaawansowane technologie i badania naukowe $\mathrm{z}$ różnych dziedzin od nauk przyrodniczych, ekonomicznych, na filozoficznych kończąc. Można $\mathrm{z}$ całą pewnością stwierdzić, że ekologia jest nauką skupiającą jak w soczewce wszystkie dziedziny wiedzy. Prowadząc taką działalność można stwierdzić, że: Nie obyło się jednak bez kosztów. Uważa się, że działania człowieka prowadzą do zaburzenia naturalnych cyklów ziemi. Według niektórych naukowców wkroczyliśmy w nową epokę geologiczną, zwaną antropocenem (termin zaproponowany przez Paula Crutzena, chemika atmosfery w 2000 r.), kiedy to ludzie wywierają coraz bardziej zauważalny wpływ na całą planetę. Pragniemy uspokoić czytelników, że nadal trwa halocen epoka geologiczna, która zaczęła się blisko 12 tys. lat temu i przyniosła ludzkości rolnictwo. Początek antropogenu został ustalony przez naukowców na lata 50. XX w. Naukowcy pracujący pod kierunkiem prof. Zalasiewicza (brytyjski geolog polskiego pochodzenia z Uniwersytetu w Leicester) ustalili, że początek nowej epoki geologicznej musi być globalny. Geolodzy zmiany epok szukają w skamielinach. Oznakami narodzin antropogenu są: pierwiastki promieniotwórcze powstałe sztucznie po wybuchach jądrowych (w okresie między 1945 a początkiem 2013 liczbę prób jądrowych szacuje się na 2030), związki biogenne (azot i fosfor), które dostały się do obiegu po tzw. zielonej rewolucji, plastiki i związki stałe emitowane do atmosfery z układów wydechowych silników spalinowych oraz kominów ${ }^{3}$.

O ironio, do tej pory zmiany epok wnosiły coś do pisanej cywilizacji człowieka. Zaproponowana zmiana została ustalona przez człowieka przez jego ego, które wstydząc się trzeba nazwać po imieniu ,zaśmieceniem” planety Ziemia.

Można zatem z całą odpowiedzialnością rzec, że wiodące państwa niosące ciężar ochrony i kształtowania środowiska przyrodniczego na planecie Ziemia w porę wzięły sobie za dewizę słowa: Mahatma Gandhiego, duchowego przywódcy Indii: „Ziemia jest w stanie zaspokoić potrzeby wszystkich ludzi, nie jest jednak w stanie zaspokoić ich chciwości", które przytoczył jego, osobisty sekretarz Pyarelal Nayyar.

Cechą współczesnego polskiego słownictwa jest skłonność dodawania słowa bezpieczeństwo w celu dookreślenia czynności, zagadnienia, problemu. Nie jest to nadużycie, ale np. komunikacja sama w sobie musi być bezpieczna. Czy sformułowanie bezpieczna komunikacja zwiększa komfort podróży pasażerów?

„Bezpieczeństwo, zgodnie z definicją i potocznym rozumieniem tego pojęcia, przez długi czas było utożsamiane ze stanem gwarantującym pewność istnienia i przetrwania. Współcześnie taki pogląd jest kwestionowany jako zbyt wąski lub konserwatywny. W nowym ujęciu ma oznaczać nie tylko gwarancje nienaruszalnego przetrwania danego podmiotu, lecz także swobodę jego rozwoju. Próba ponownego zinterpretowania pojęcia bezpieczeństwo jest świadectwem wzrostu zainteresowania tą problematyką. Osoby zajmujące się nią twierdzą, że będzie to skutkowało wyodrębnieniem się nowej dyscypliny naukowej - securitologii, której obszar zainteresowań obejmie badania dotyczące zagro-

\footnotetext{
${ }^{3}$ http://wyborcza.pl/1,75400,20620239,poczatek-antropocenu-po-smieciach-nas-poznacie.html (dostęp: 19.12.2016 r.).

${ }^{4}$ http://wol.jw.org/pl/wol/d/r12/lp-p/2014642\#h=2] (dostęp: 12.11.2016 r.).
} 
żeń odnoszących się do istnienia, rozwoju i normalnego funkcjonowania człowieka i organizacji społecznych"5.

„Bezpieczeństwo jest terminem interdyscyplinarnym. Badaniem jego aspektów zajmuje się wiele różnych dziedzin nauki. Należą do nich historia, psychologia, socjologia, nauki prawne, politologia $i$ wiele innych. Już po bogactwie nauk zajmujacych się tym problemem można wnioskować, że pojęcie »bezpieczeństwa« jest bardzo bogate jeżeli chodzi o znaczenia i definicje. Wadą takiej sytuacji jest pewna niedookreśloność tego terminu gdyż każdy badacz, każda dziedzina nauki zajmuje się różnymi aspektami bezpieczeństwa"6.

Do niedawna słowo bezpieczeństwo wyłączone było ze środowiska, można powiedzieć zrywało więzi z otoczeniem, zatem uległo alienacji. W dzisiejszym świecie nie występuje już samodzielnie. Występuje z drugim słowem np. w strategii bezpieczeństwa Koziej pisze: „Najbardziej generalne kształtowanie bezpieczeństwa jest zadaniem strategii i poprzez strategię jest ono realizowane. Najogólniej rzecz biorąc, strategia to kategoria prakseologiczna, czyli dotycząca sprawnego działania każdego podmiotu i odnosząca się do najbardziej generalnych sposobów tego działania. Strategia bezpieczeństwa zaś to jedna $\mathrm{z}$ wielu dziedzin strategii w ogóle odnosząca się do zapewniania bezpieczeństwa danego podmiotu. Strategia bezpieczeństwa - to teoria i praktyka kierowania sprawami bezpieczeństwa danego podmiotu przez naczelnego decydenta (indywidualnego lub zbiorowego), w tym zwłaszcza ustalania celów bezpieczeństwa oraz sposobów ich osiągania"?.

Takie zestawienie słów przeciętnego czytelnika nie irytuje. Natomiast w zestawieniu bezpieczeństwo ekologiczne w opinii badanych wywołuje różne rozumienie. Te różnice zostały zbadane przez autorów.

\section{ANALIZA BADANEGO SŁOWNICTWA, UŻYWANEGO W STRATEGIACH BEZPIECZEŃSTWA NARODOWEGO RZECZYPOSPOLITEJ POLSKIEJ Z 2003, 2007 I 2014 ROKU}

Rozdział ten przedstawia ewolucję opisywanych pojęć dotyczących omawianych zagadnień w trzech opublikowanych Strategiach Bezpieczeństwa Narodowego, do których zobowiązuje Konstytucja. Wszystkie strategie opracowane zostały w oparciu o tę samą Konstytucję. Z historycznego obowiązku należy dodać, że w dniu 2 listopada 1992 r. prezydent Lech Wałęsa przyjął dwa dokumenty opracowane przez Komitet Obrony Kraju: „Założenia polskiej polityki bezpieczeństwa” oraz „Polityka bezpieczeństwa i strategia obronna Rzeczypospolitej Polskiej”. Tym samym po raz pierwszy po wolnych, demokratycznych wyborach w 1989 r., na nowo określone zostały założenia polskiej racji stanu,

\footnotetext{
5 P. Majer, W poszukiwaniu uniwersalnej definicji bezpieczeństwa wewnętrznego, „Przegląd Bezpieczeństwa Wewnętrznego" 7/12, cejsh.icm.edu.pl/cejsh/element/bwmeta1.element...8840.../ PBW_nr_7.11-19.pdf (dostęp: 12.11.2016 r.).

${ }^{6}$ Pojęcie bezpieczeństwa - Geopolityka.net - polski portal o geopolityce..., geopolityka.net/pojeciebezpieczenstwa/ (dostęp: 12.11.2016 r.).

${ }^{7}$ Bezpieczeństwo: istota, podstawowe kategorie i historyczna ewolucja, https://www.bbn.gov.pl/.../ Bezpieczenstwoistotapodstawowekategorieihistorycznaewol... (dostęp: 12 listopada 2016)
} 
jak też zdefiniowano bezpieczeństwo państwa w nowych uwarunkowaniach politycznomilitarnych Europy lat $90 .^{8}$. Dokument ten przez autorów nie jest analizowany.

W artykule 5. Konstytucja Rzeczypospolitej Polskiej z 1997 roku stwierdza, że Polska „(...) zapewnia ochronę środowiska, kierując się zasadą zrównoważonego rozwoju”, zaś artykuł 74 brzmi: 1. Władze publiczne prowadzą politykę zapewniającą bezpieczeństwo ekologiczne współczesnemu i przyszłym pokoleniom. 2. Ochrona środowiska jest obowiązkiem władz publicznych. 3. Każdy ma prawo do informacji o stanie i ochronie środowiska. 4. Władze publiczne wspierają działania obywateli na rzecz ochrony i poprawy stanu środowiska9 .

Zagadnienia sozologii są nie tylko bliskie miłośnikom przyrody, ale przykuwają na szczęście coraz częściej uwagę polityków i specjalistów bezpieczeństwa wewnętrznego i międzynarodowego. Polityka ekologiczna w kraju nie ma należytej siły „,przebicia”. W dniu 8 września 2003 roku w Belwederze pod przewodnictwem Prezydenta RP Aleksandra Kwaśniewskiego odbyło się posiedzenie Rady Bezpieczeństwa Narodowego. Prezydent podpisał Strategię Bezpieczeństwa Narodowego Rzeczypospolitej Polskiej [1]. Kolejną Strategię Bezpieczeństwa Narodowego Rzeczypospolitej Polskiej zatwierdził Prezydent RP Lech Kaczyński 13 listopada 2007 roku [2].

Obowiązującą Strategię Bezpieczeństwa Narodowego RP Prezydent Rzeczypospolitej Polskiej Bronisław Komorowski podpisał 5 listopada 2014 r., na wniosek Prezesa Rady Ministrów [3].

Tabela 1. Pojęcia i słownictwo używane w opublikowanych Strategiach Bezpieczeństwa Narodowego Rzeczypospolitej Polskiej

\begin{tabular}{|c|c|c|}
\hline \multicolumn{3}{|c|}{ Strategia Bezpieczeństwa Narodowego Rzeczypospolitej Polskiej } \\
\hline $\begin{array}{l}\text { z dnia } 8 \text { września } \\
2003^{10} \text { roku [1] }\end{array}$ & $\begin{array}{l}\text { z dnia } 13 \text { listopada } \\
2007^{11} \text { roku [2] }\end{array}$ & $\begin{array}{l}\text { z dnia } 5 \text { listopada } \\
2014^{12} \text { roku [3] }\end{array}$ \\
\hline $\begin{array}{l}\text { 4. Środowisko naturalne. } \\
\text { W celu zagwarantowania bezpie- } \\
\text { czeństwa ekologicznego Polska } \\
\text { będzie kontynuować działania na } \\
\text { rzecz ochrony środowiska, kieru- } \\
\text { jąc się zasada zrównoważonego } \\
\text { rozwoju, tak aby zachowywać } \\
\text { równowage przyrodnicza oraz } \\
\text { trwatość podstawowych procesów } \\
\text { przyrodniczych w biosystemie. } \\
\text { Będziemy również wdrażać sys- } \\
\text { tem bezpieczeństwa biologiczne- } \\
\text { go. Polska będzie nadal aktywnie }\end{array}$ & $\begin{array}{l}\text { Koncepcja bezpieczeństwa naro- } \\
\text { dowego. Cele i zadania sektorowe. } \\
\text { 1. Bezpieczeństwo zewnętrzne; } \\
\text { 2. Bezpieczeństwo militarne; } \\
\text { 3. Bezpieczeństwo wewnętrzne; } \\
\text { 4. Bezpieczeństwo obywatelskie; } \\
\text { 5. Bezpieczeństwo społeczne; } \\
\text { 6. Bezpieczeństwo ekonomiczne; } \\
\text { 7. Bezpieczeństwo ekologiczne; } \\
\text { 3.7. Bezpieczeństwo ekologiczne } \\
\text { 75. Nadrzędnym celem działań } \\
\text { państwa w obszarze bezpieczeń- } \\
\text { stwa ekologicznego jest zapewnie- }\end{array}$ & $\begin{array}{l}\text { 11. Rzeczpospolita Polska zapewnia } \\
\text { bezpieczeństwo państwa i obywateli } \\
\text { poprzez stwarzanie warunków do re- } \\
\text { alizacji interesów narodowych i osia- } \\
\text { gania celów strategicznych. Interesy } \\
\text { narodowe określa art. } 5 \text { Konstytucji } \\
\text { Rzeczypospolitej Polskiej. Z nich } \\
\text { wynikaja interesy narodowe w dzie- } \\
\text { dzinie bezpieczeństwa, do których } \\
\text { należa: } \\
\text { - zapewnienie trwatego i zrównowa- } \\
\text { żonego rozwoju potencjatu spotecz- } \\
\text { nego i gospodarczego państwa, ze }\end{array}$ \\
\hline
\end{tabular}

${ }^{8}$ Założenia polityki bezpieczeństwa i strategia obronna..., koziej.pl/wp-content/uploads/2015/07/ Strategia_RP_z_92_r.doc (dostęp: 12.11.2016 r.).

${ }_{9}$ Konstytucja RP, tekst uchwalony w dniu 2 kwietnia 1997r. przez Zgromadzenie Narodowe (Dz.U. z 1997 r., nr 78, poz. 483) (dostęp: 12.11.2016 r.).

10 http://bip.kozienice.pl/dokument-2152-strategia_bezpieczenstwa_narodowego.html (dostęp: 14 . 11.2016)

${ }^{11} \mathrm{http} / / /$ www.msz.gov.pl/resource/7d18e04d-8f23-4128-84b9-4f426346a112 (dostęp: 14 listopada 2016 r.).

${ }^{12}$ https://www.bbn.gov.pl/ftp/SBN\%20RP.pdf (dostęp: 14.11.2016 r.). 


\begin{tabular}{|c|c|c|}
\hline $\begin{array}{l}\text { uczestniczyć we wspótpracy mię- } \\
\text { dzynarodowej na rzecz ochrony } \\
\text { śodowiska, w tym zapewnienia } \\
\text { bezpieczeństwa ekologicznego } \\
\text { kraju, zwłaszcza w kontekście } \\
\text { transgranicznego przeptywu za- } \\
\text { nieczyszczen powietrza, zanie- } \\
\text { czyszczenia wód granicznych oraz } \\
\text { skutków awarii przemystowych } \\
\text { i transportowych. Polska będzie } \\
\text { brać udziat zarówno we wspót- } \\
\text { pracy regionalnej, w realizacji } \\
\text { programów dziatania wypraco- } \\
\text { wanych przez UE, ONZ oraz } \\
\text { OECD, jak i-na miare swoich } \\
\text { możliwości - w rozwiąywaniu } \\
\text { globalnych problemów ekologicz- } \\
\text { nych oraz w petni realizować } \\
\text { przyjęte na siebie zobowiązania } \\
\text { międzynarodowe w tejdziedzinie. }\end{array}$ & 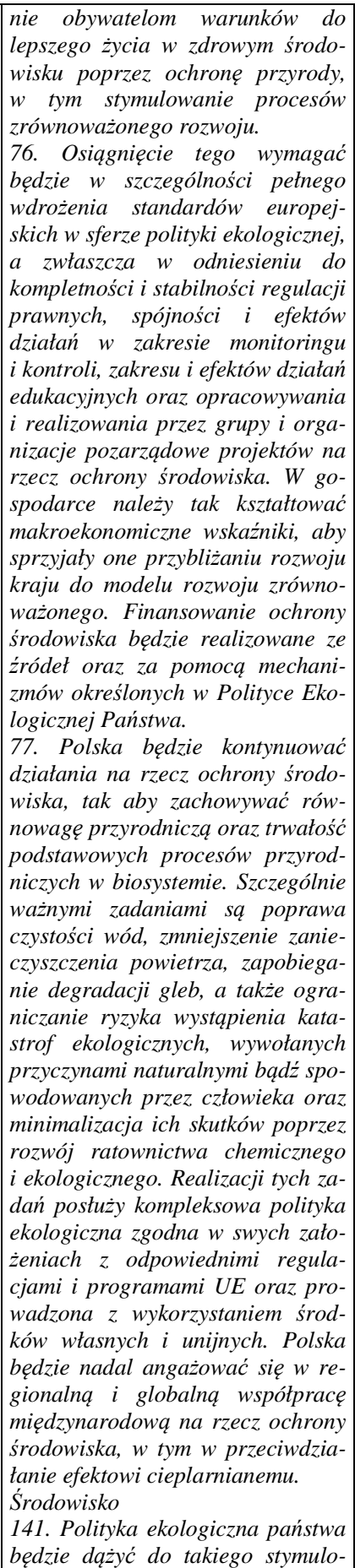 & 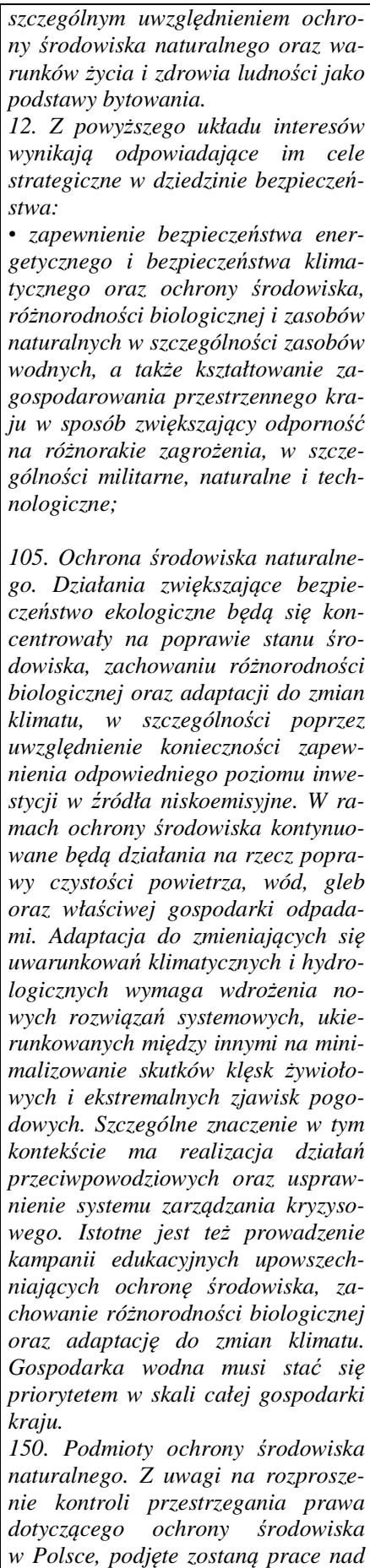 \\
\hline
\end{tabular}




\begin{tabular}{|c|c|c|}
\hline & $\begin{array}{l}\text { wania procesów rozwoju kraju, aby } \\
\text { wak najmniejszym stopniu zagra- } \\
\text { zaty środowisku i jego zasobom. } \\
\text { Jej urzeczywistnianie powinno się } \\
\text { odbywać w ścistym zwiazku ze } \\
\text { strategiami i politykami wspólno- } \\
\text { towymi, a zwtaszcza odnowionymi } \\
\text { strategia lizbońska i strategia } \\
\text { zrównoważonego rozwoju UE. } \\
\text { Wszystkie strategie i polityki se- } \\
\text { ktorowe muszq uwzględniać zato- } \\
\dot{z} \text { enia } i \text { zasady polityki ekologicz- } \\
\text { nej. } \\
142 . \quad \text { Należy stworzyć na bazie } \\
\text { istniejacych aktów prawnych } \\
\text { czytelne, prostsze w stosowaniu } \\
\text { prawo środowiskowe. Istnieje ko- } \\
\text { nieczność precyzyjnego unormo- } \\
\text { wania prawnego prowadzenia akcji } \\
\text { ratowniczych i określenia źródet } \\
\text { ich finansowania. Należy także } \\
\text { opracować } i \text { aktualizować plany } \\
\text { ewakuacji ludności oraz zabezpie- } \\
\text { czenia jej warunków do przetrwa- } \\
\text { nia przez określony czas. Zasadne } \\
\text { jest również prowadzenie aktywnej } \\
\text { edukacji proekologicznej spote- } \\
\text { czeństwa. }\end{array}$ & $\begin{array}{l}\text { wzmocnieniem i usprawnieniem dzia- } \\
\text { tań stużb ochrony środowiska. Roz- } \\
\text { wijana będzie wspótpraca międzyna- } \\
\text { rodowa w obszarze bezpieczeństwa } \\
\text { ekologicznego, wspierajaca organi- } \\
\text { zacje i porozumienia międzynarodo- } \\
\text { we na rzecz ograniczania emisji } \\
\text { zanieczyszczén, globalnej polityki kli- } \\
\text { matycznej i zachowania różnorodno- } \\
\text { ści biologicznej, respektujace poziom } \\
\text { rozwoju i strukturę gospodarek na- } \\
\text { rodowych państw uczestniczacych. }\end{array}$ \\
\hline
\end{tabular}

Źródło: opracowanie własne na podstawie opublikowanych strategii.

W celu dokonania uproszczonej analizy tekstu strategie zostały ponumerowane w kolejności ich powstawania. We wszystkich strategiach pojawia się pojęcie bezpieczeństwo ekologiczne. Przy czym w [1] wyprowadzane jest z środowiska naturalnego, co zdaniem autorów i badanych jest rzeczą zupełnie naturalną. Strategie z reguły są dokumentem bardzo zwartym i nakreślają kardynalne kierunki. Jak na pierwszy dokument tego typu w zasadzie podano jasne wskazówki do dalszego działania i prac.

W strategii [2] po raz pierwszy wyodrębniono bezpieczeństwo ekologiczne jako jedno z siedmiu bezpieczeństw państwa. Takie rozwiązanie można uznać za innowacyjne. Pytanie, które się nasuwa brzmi: czy autorzy takiej koncepcji pójdą w tym kierunku i czy w dalszej perspektywie nie należało wyodrębnić kolejnego, na przykład bezpieczeństwo żywnościowe? Bezpieczeństwo żywnościowe mogłoby mieć samodzielny byt. Powinno ono skupić zagadnienia z szeroko rozumianymi zagadnieniami zaspokojenia potrzeb żywnościowych społeczeństwa. Problem jest nie mały z powodu produkcji żywności metodami przemysłowymi i to zarówno tej: zwierzęcej, rybackiej, rolnej czy wreszcie sadowniczej czy ogrodniczej. Zastosowanie coraz większej ilości środków chemicznych zarówno potrzebnych do produkcji jak i jej ochrony budzi w społeczeństwie coraz większe zaniepokojenie. Osobnym zagadnieniem jest i będzie zastosowanie osiągnięć genetyki w uprawianej i hodowlanej florze i faunie. Problemy genetycznie modyfikowanej żywności (GMO, z ang. genetically modified organisms - organizmy, których genom został zmieniony metodami inżynierii genetycznej w celu uzyskania nowych cech fizjologicz- 
nych (lub zmiany istniejących) ${ }^{13}$, staną już w najbliższej przyszłości jako problem do rozwiązania.

Zdaniem autorów ten rodzaj bezpieczeństwa nazwany umownie bezpieczeństwem żywnościowym, powinien zostać wyodrębniony chociażby z prostego powodu, że dotyczy całej populacji biotopu w siedlisku. Na dzień dzisiejszy brak jest jednoznacznych badań opisujących oddziaływanie na środowisko naturalne. Przewidywane prognozy niektórych naukowców dopuszczają również wariant katastrofy genetycznej.

Strategia [3] z racji roku opracowania jest najbardziej rozbudowana. Zawiera niemal wszystko. Godne zauważenia są treści w punkcie $105, \ldots$,..Szczególne znaczenie w tym kontekście ma realizacja działań przeciwpowodziowych oraz usprawnienie systemu zarządzania kryzysowego..."

Zdaniem autorów tego artykułu, aż się prosi wprowadzenie pojęcia sozologii tak trafnie zdefiniowanego przez polskiego uczonego Walerego Goetela. Można z całą pewnością powiedzieć, że wszystkie trzy strategie są zgodne, że naturalnego środowiska już nie ma. Pozostałe jego enklawy w najbliższej przyszłości mogą zostać przekształcone chociażby przez GMO, które przecież nie zna granic. Czas zatem mówić o ochronie i kształtowaniu środowiska. Rozumiejąc ochronę jako wprowadzanie technologii jak najmniej inwazyjnych, a kształtowanie jako odtwarzanie lub tworzenie nowego z minimalną zmianą środowiska pierwotnego.

W Rzeczypospolitej Polskiej kwestia ochrony środowiska staje się problemem coraz bardziej istotnym wśród wielu innych trudnych zagadnień do rozwiązania. Nie przybędzie nam inwestycji chroniących środowisko naturalne człowieka od akademickiego polemizowania na temat zdefiniowania pojęć opisujących to środowisko. Jednak kształtowanie świadomości i upowszechnianie wiedzy ekologicznej jest skutecznym i niezbędnym środkiem zmniejszania oddziaływania oraz minimalizacji efektów negatywnego wpływu ludzi i wykorzystywanych środków na środowisko. Rekapitulując ochrona środowiska, kształtowanie środowiska, bezpieczeństwo ekologiczne nie powinny być używane zamiennie.

Zdaniem autorów artykułu pojęcia te powinno się zastąpić sozologią. Sozologia - (pochodzi od greckiego słowa sodzo, które oznacza „ochraniać”, „ratować”, „pomagać”). termin zaproponowany przez polskiego uczonego Goetela. Jest to nauka o ochronie i kształtowaniu środowiska. Zadaniem sozologii jest opracowanie teoretycznych podstaw rekultywacji zniszczonych środowisk i przyrodniczego zagospodarowania środowiska w sposób jak najbardziej korzystny ze względów przyrodniczych, ekonomicznych i estetycznych ${ }^{14}$.

Józef Dołęga w artykule: „Filozofia nauk o ochronie środowiska i kultura ekologiczna” pisze ${ }^{15}$ : „W aspekcie metodologicznym treści nazwy „sozologia” mówi się przede

${ }^{13}$ http://www.biotechnolog.pl/gmo (dostęp: 14.11.2016 r.).

${ }^{14}$ Prof. zw. dr hab. Walery Goetel, urodził się 14 kwietnia 1889 roku w Suchej (dziś Sucha Beskidzka). Zmarł 6 listopada 1972 roku w Krakowie i tam też pochowany w Alei Zasłużonych na Cmentarzu Rakowickim. Opracował m.in. naukowe podstawy i zasady racjonalnej gospodarki zasobami geologicznymi i biologicznymi, przedstawił program i zakres nowej nauki o ochronie przyrody i jej zasobów, o przyrodniczych podstawach kształtowania środowiska naturalnego człowieka, wprowadził zaakceptowaną i używaną na całym świecie nazwę tej nauki - sozologia.

15 http://bazhum.muzhp.pl/media//files/Studia_Philosophiae_Christianae/Studia_Philosophiae_ Christianae-r2000-t36-n2/Studia_Philosophiae_Christianae-r2000-t36-n2-s67-79/Studia_ Philosophiae_Christianae-r2000-t36-n2-s67-79.pdf (dostęp: 11.11.2016 r.). 
wszystkim o metodach służących do badań przedmiotu tej nauki. Wyróżnia się tutaj metody empiryczne, humanistyczne, filozoficzne i systemowe".

„Natomiast w aspekcie przedmiotowym nazwy ,,sozologia” podkreśla się zagadnienia i problemy wchodzące w zakres naukowych badań sozologicznych. Przykładowo wymienia się tutaj takie problemy i zagadnienia jak ${ }^{16}$ :

- „opis faktyczny stanu przyrody w Polsce i świecie;

- określenie obiektów, które zanieczyszczają i niszczą środowisko;

- przeprowadzenie badań technicznych i technologicznych w celu wprowadzania urządzeń oczyszczających i technologii nieuciążliwych dla środowiska;

- badanie wpływu zmienionego środowiska na organizmy żywe i na człowieka;

- tworzenie zabezpieczeń prawnych i administracyjnych w skali krajowej i międzynarodowej w celu realizacji programów ochrony środowiska;

- budzenie świadomości moralnej i etycznej wrażliwej na jakość środowiska przyrodniczego i społecznego;

- szukanie środków zmniejszających zanieczyszczenie środowiska i eliminowanie źródeł tych zanieczyszczeń;

- badanie wpływu środowiska na stan psychiczny człowieka;

- prowadzenie medycznych badań nowych jednostek chorobowych, powstałych pod wpływem zmienionego środowiska;

- zabezpieczenie tak zwanych ,czystych” rezerw genetycznych;

- wychowanie - na różnych szczeblach edukacji narodowej - w duchu wrażliwości na wartość środowiska człowieka".

„Zakres nazwy »sozologii« obejmuje problemy i zagadnienia dotyczące środowiska przyrodniczego i społecznego, w którym żyje człowiek. A zatem dotyczy przyrody nieożywionej i ożywionej oraz antroposfery. Wszystkie te obszary rozpatrywane są w aspekcie ochrony naturalnych właściwości poszczególnych obiektów przyrodniczych i ich wpływu na życie i zdrowie człowieka. W aspekcie tym, który jest charakterystyczny dla sozologii, mieszczą się badania naturalnych właściwości obiektów przyrody nieożywionej i ożywionej oraz ich właściwości powstałych pod wpływem działalności człowieka. Badania te dotyczą również nowo powstałych właściwości środowiska i ich wpływu na zdrowie i życie człowieka, a także ich wpływu na kondycję biologiczną innych gatunków żyjących na Ziemi”"17.

Uważny czytelnik literatury przedmiotu zauważa, że chyba nieuprawnionym na obecnym etapie jest przypisywanie roli ,,pierwszych skrzypiec” bezpieczeństwu ekologicznemu i stosowanie go wymiennie z dziedzinami nauki takimi jak ekologia i sozologia.

Próbą potwierdzenia roboczej tezy; „Czy uprawnione staje się ewolucyjne ,przejście” pojęć typowych i przypisywanych ekologii do bezpieczeństwa ekologicznego" jest analiza dostępnej literatury jak też rozmowy z osobami zajmującymi się tą problematyką.

Spory pomiędzy zwolennikami i przeciwnikami roboczej tezy w środowisku trwają od lat. Obecnie mamy powody - patrz badania, aby w środowisku badaczy zajmujących się tą problematyką wywołać polemikę, której efektem ma być „uporządkowanie” słownictwa. Zależy nam, aby do dyskusji włączyli się nie tylko ekolodzy, biolodzy, przyrodnicy i filolodzy ale przede wszystkim politolodzy oraz decydenci związani z szeroko rozumia-

\footnotetext{
16 Ibidem.

17 Ibidem.
} 
nym bezpieczeństwem. Będzie to oznaką zmieniających się czasów, którą to zmianę wywołali wymienieni jako ostatni. Układ relacji teza - pytanie badawcze może zatem przybrać formę następującą.

Teza: Działania ludzi odpowiedzialnych za ekologię nie w pełni odpowiadają współczesnym wyzwaniom.

Logiczne wynikające stąd pytania badawcze są następujące:

1. Jakie są problemy ekologii jako nauki i współczesnej ekologii, jakże często utożsamianej z bezpieczeństwem ekologicznym?

2. Jakie działania podejmuje środowisko z głównego nurtu, a jakie z ,towarzyszącego - bezpieczeństwa", by je rozwiązać?

3. Czy realizowane działania służą rozwiązywaniu problemów współczesnej ekologii i bezpieczeństwa ekologicznego?

Zagadnienia te wymagają dalszych badań. Na dzień dzisiejszy autorzy prezentują wyniki badań ankietowych, które pogłębiają ich wątpliwości.

\section{BADANIA WŁASNE}

Badania naukowe to obok kształcenia i wychowania najważniejsza sfera aktywności nauczycieli akademickich.

Badania naukowe rozpoczynają się od poszukania problemu badawczego w rzeczywistej sytuacji problemowej. Ograniczenia edytorskie są powodem, że nasze rozważania składają się z dwóch części. W pierwszej części artykułu przedstawiono metodologię i cel naszych badań. $\mathrm{Z}$ uwagi na to, że obydwa artykuły mogą istnieć samodzielnie, ale razem tworzą pełny i przestrzenny obraz badanej rzeczywistości. Szanując czytelników drugiego artykułu, w skrócie przypominamy nasze etapy procesu badawczego.

Wybór problemu badawczego był podyktowany zamiennym, często nieuzasadnionym stosowaniem pojęć związanych z ekologią, sozologią, ochroną przyrody, kształtowaniem i ochroną środowiska w: Strategii Bezpieczeństwa Narodowego Rzeczypospolitej Polskiej w opinii badanych.

Podstawowym celem przeprowadzonych badań było poznanie rozróżniania pojęć:

- ekologia,

- bezpieczeństwo ekologiczne.

Obiektem naszych badań była grupa 60 osób (tyle samo kobiet i mężczyzn), które funkcjonowały w nowej rzeczywistości po roku 90. Oceniliśmy, czy nowe słownictwo i pojęcia, które jest typowe dla okresu życia badanych uszło ich uwadze czy zauważają ich rozróżnialność znaczeniową.

Na wykresie 1 przedstawiono akceptację udziału w badaniach wytypowanych kobiet i mężczyzn.

Jak wynika z przeprowadzonych badań większą grupę, która odmówiła w nich udziału stanowią kobiety (z 30 ankietowanych, 33\% to respondentki, które opuściły terytorium Polski na przełomie wieku, założyły rodziny ,na zachodzie” posiadają podwójne obywatelstwo i nie znają współczesnych realiów naszego kraju. Z kolei w przypadku mężczyzn tylko 19\% odmówiło badania $\mathrm{z}$ następujących powodów: 2 jest oficerami marynarki handlowej, 3 pracuje na zagranicznych kontraktach i podobnie jak kobiety wyrażają swoją niechęć do udziału w badaniach. 


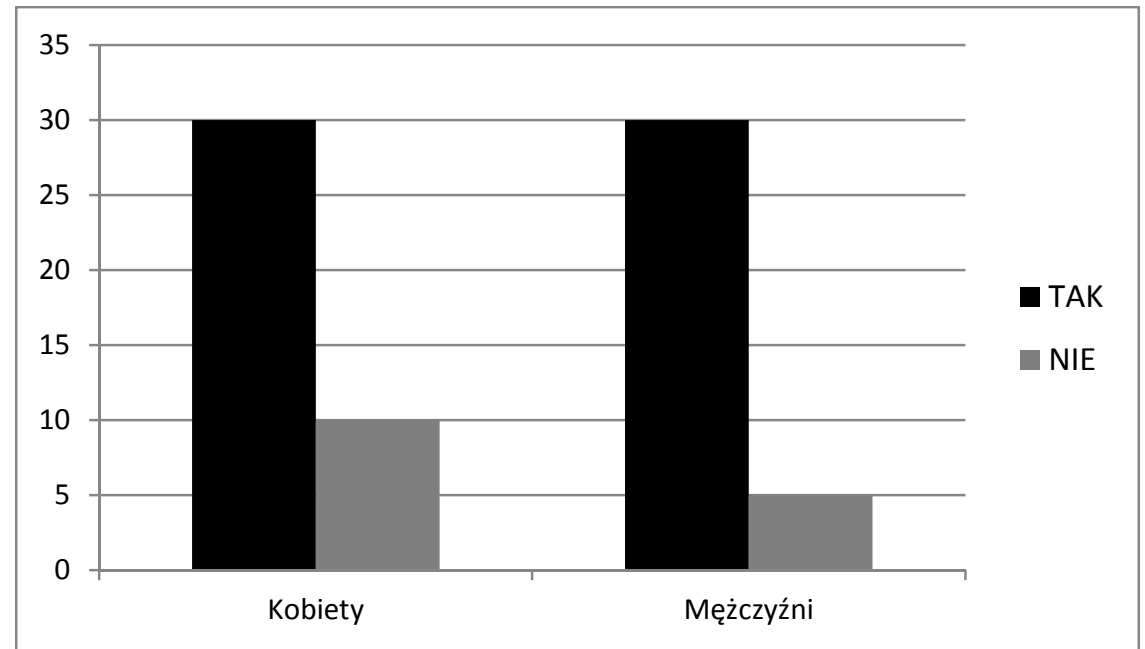

Wykres 1. Populacja badanych

Źródło: badania własne.

Na wykresie 2 przedstawiono typ ukończonych studiów przez osoby biorące udział w badaniach.

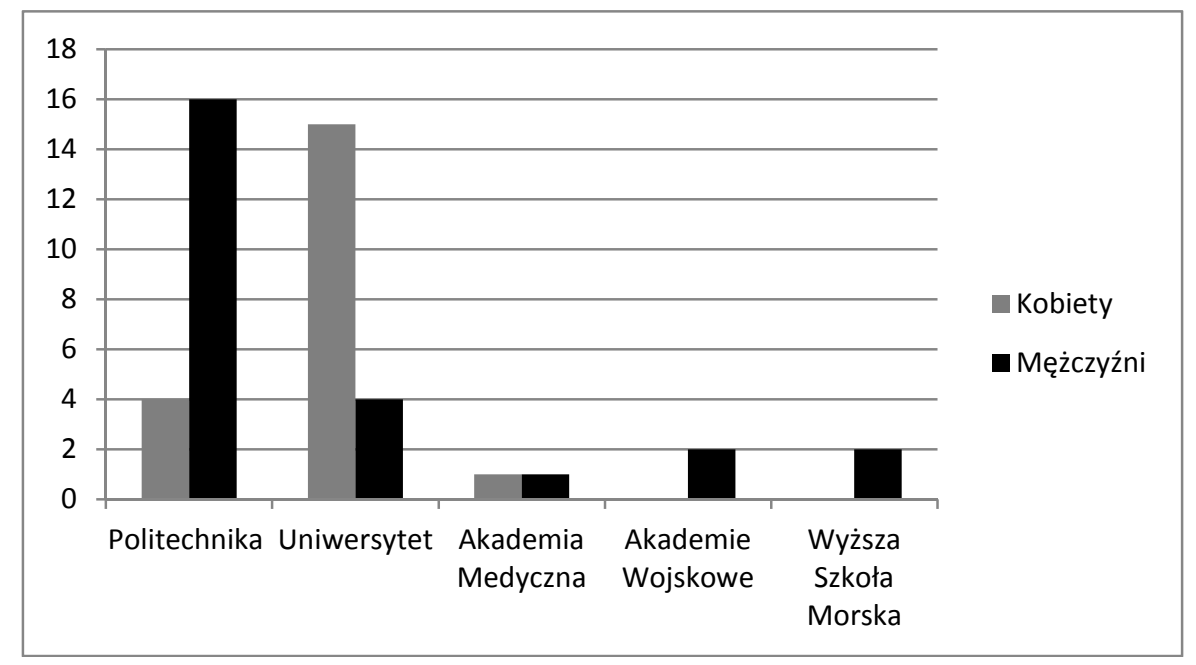

Wykres 2. Typ ukończenia uczelni

Źródło: badania własne.

Autorzy operują dawnym nazewnictwem uczelni obowiązującym w okresie otrzymania dyplomu przez badanych. Kobiety zdominowały wykształcenie uniwersyteckie. Równowagę wykształconych osiągnięto na Akademii Medycznej. Politechniczne wykształce- 
nie zdominowali mężczyźni kończąc odpowiednio politechnikę, akademie wojskowe i Wyższą Szkołę Morską.

Na wykresach 3 i 4 przedstawiono odpowiedzi ankietowanych, których zapytano: Czy ekologia kojarzy się Pani/Panu z dokumentem: „Strategia Bezpieczeństwa Narodowego Rzeczypospolitej Polskiej”?

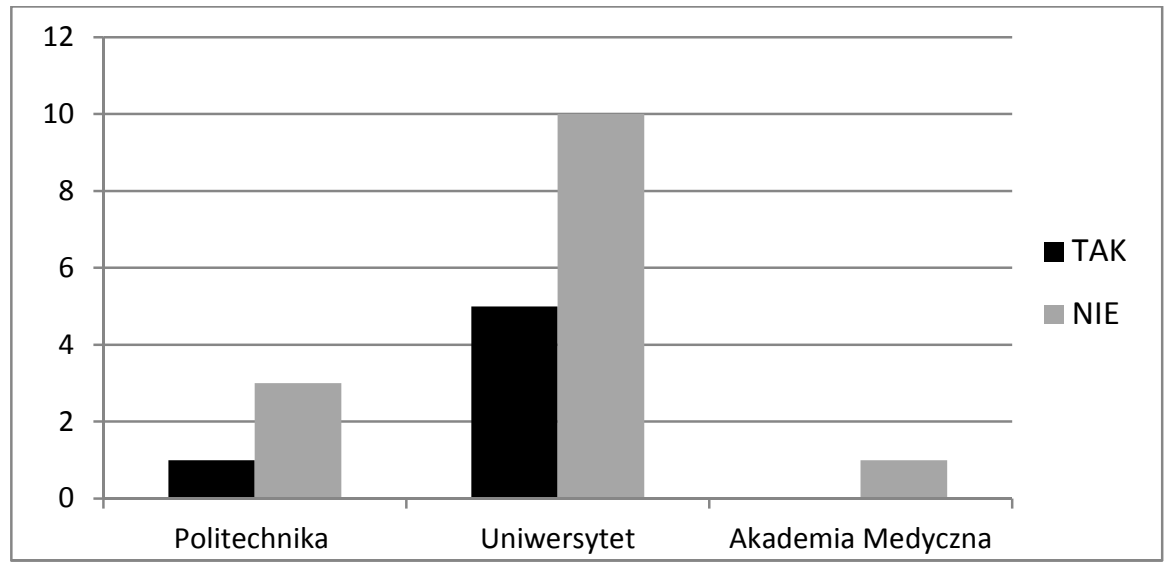

Wykres 3. Odpowiedzi kobiet: Czy ekologia kojarzy się Pani z dokumentem: „Strategia Bezpieczeństwa Narodowego Rzeczypospolitej Polskiej”?

Źródło: badania własne.

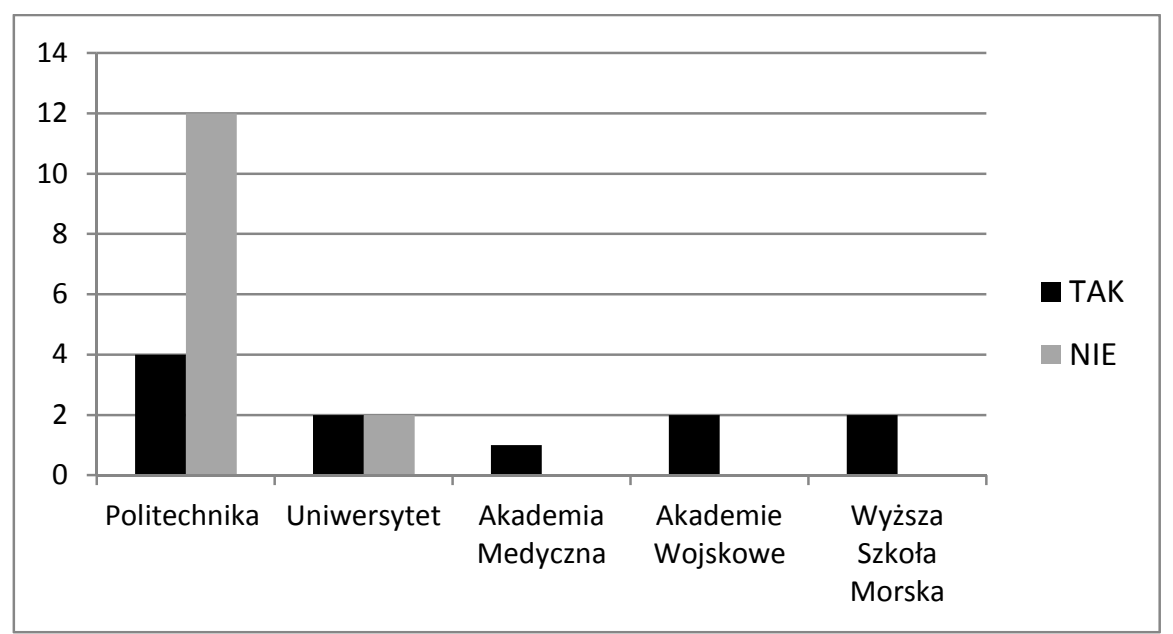

Wykres 4. Odpowiedzi mężczyzn: Czy ekologia kojarzy się Panu z dokumentem: „Strategia Bezpieczeństwa Narodowego Rzeczypospolitej Polskiej”?

Źródło: badania własne. 
Badane (wykres 3) kobiety z Politechniki w 3 przypadkach odpowiedziały „nie” i 1 raz tak. Te pierwsze kończyły kierunki ścisłe: 2 matematyka i 1 informatyka. Jedynie respondentka, która ukończyła budownictwo lądowe odpowiedziała „tak”. Tłumaczyć to można profilem studiów, gdzie prace prowadzi się na „budowie” i są tam teoretyczne i praktyczne przedsięwzięcia, chociażby ocena oddziaływania inwestycji na środowisko naturalne człowieka. Ankietowane, które zdobyły wykształcenie uniwersyteckie na tak odpowiedziały w 5 przypadkach, głównie z kierunków: chemia - 2, biologia - 3. Pozostałe badane będące na ,tak" reprezentują takie kierunki jak: prawo, historia, filologia. Dziwić może odpowiedź absolwentki Akademii Medycznej, która wybrała odpowiedź - nie.

Nieco inny obraz wynika z odpowiedzi mężczyzn.

Czterech mężczyzn (wykres 4), którzy ukończyli budownictwo lądowe (2) /morskie (2) odpowiedziało na - tak. Dwunastu respondentów odpowiedziało na - nie. W tej grupie badanych tylko 3 ukończyło kierunki ścisłe - 1 informatyka, 2 fizyka. Z kolei 9 badanych ukończyło kierunki praktyczne: geodezja - 3, elektrotechnika ogólna - 4, elektronika - 2 . Zastanawiające są odpowiedzi geodetów, jest to zawód mimo wszystko „terenowy”, gdzie czynności wykonuje się w większości poza biurem. Jednak odpowiedzi absolwentów mogą nie dziwić, albowiem obecnie większość prac wykonuje się w biurze projektowym, a dokonanie pomiaru nie zajmuje tyle czasu, co kilkanaście lat wstecz na skutek wprowadzenia nowych technik pomiarowych (np. korzystanie z satelitarnego systemu GPS Global Positioning System).

Koleje pytanie, które zadano ankietowanym brzmiało: „Czy Konstytucja Rzeczpospolitej Polskiej ma w swojej treści artykuł: o ochronie środowiska i bezpieczeństwie ekologicznym?"

Celowo to pytanie zadano jako drugie. Nie dziwi rozkład odpowiedzi kobiet - Czy Konstytucja ma w swojej treści artykuł: „ochrona środowiska”?, natomiast zastanawiająca jest odpowiedź na pytanie Czy Konstytucja ma w swojej treści artykuł: „bezpieczeństwo ekologiczne"? Tak odpowiedziały 4 ankietowane, nie 2. Dziwić może postawa asekuracyjna - łącznie 14 respondentek z rozbiciem na odpowiednio: 8 - raczej tak, 6 raczej nie.

Odpowiedzi mężczyzn na pytanie - Czy Konstytucja ma w swojej treści artykuł: „ochrona środowiska”, nie stanowią zaskoczenia. Natomiast zastanawiające są odpowiedzi mężczyzn na pytanie - Czy Konstytucja ma w swojej treści artykuł: „,bezpieczeństwo ekologiczne"? Tak - odpowiedziało 5 badanych mężczyzn, a jeden zaznaczył odpowiedź - nie. Zaskakująca jest postawa asekuracyjna - łącznie 19 respondentów z rozbiciem odpowiednio na: 11 - raczej tak, 8 - raczej nie.

Autorzy nie znając przyczyn ,asekuracyjnych” odpowiedzi dla pytania: Czy Konstytucja ma w swojej treści artykuł: „ochrona środowiska”? - zestawili porównawczo odpowiedzi badanych ze względu na płeć (wykres 5).

Wykres 5 nie wykazuje ,znaczących” różnic między kobietami a mężczyznami. W obydwu grupach nie było odpowiedzi nie. Zdecydowana większość respondentów, zarówno kobiet jak i mężczyzn wskazała odpowiedź - tak.

Autorzy nie znając przyczyn ,asekuracyjnych” odpowiedzi dla pytania: Czy Konstytucja ma w swojej treści artykuł: „,bezpieczeństwo ekologiczne”? - zestawili odpowiedzi kobiet i mężczyzn (wykres. 6). 


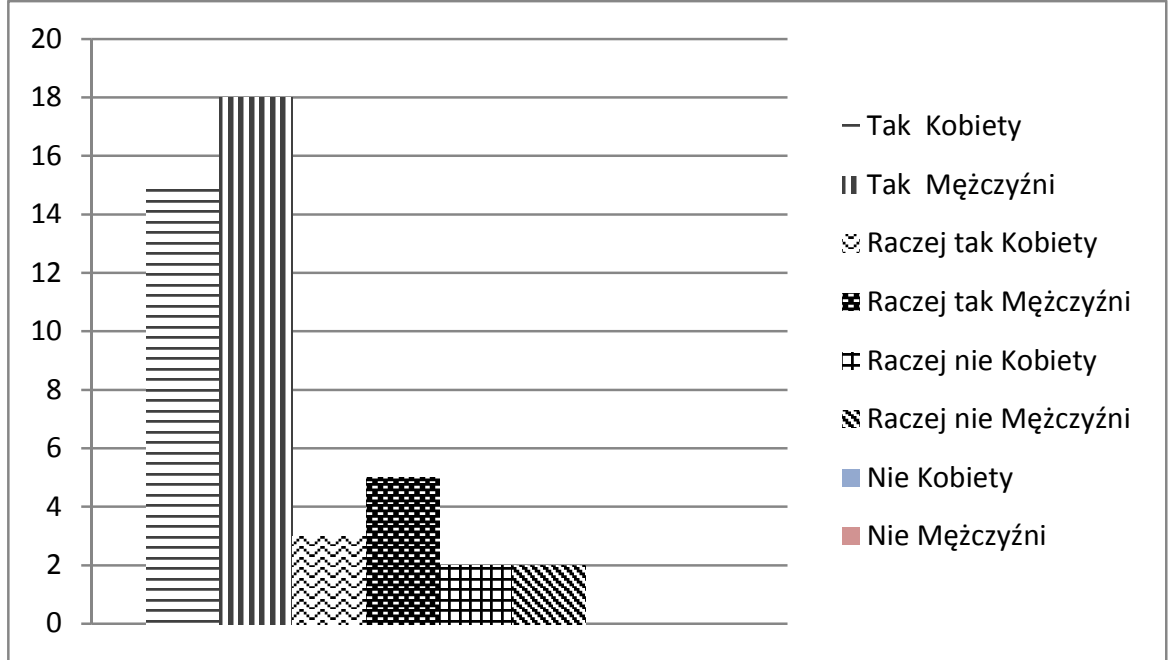

Wykres 5. Porównanie odpowiedzi kobiet i mężczyzn na pytanie: „Czy Konstytucja ma w swojej treści artykuł: „ochrona środowiska”?

Źródło: badania własne.

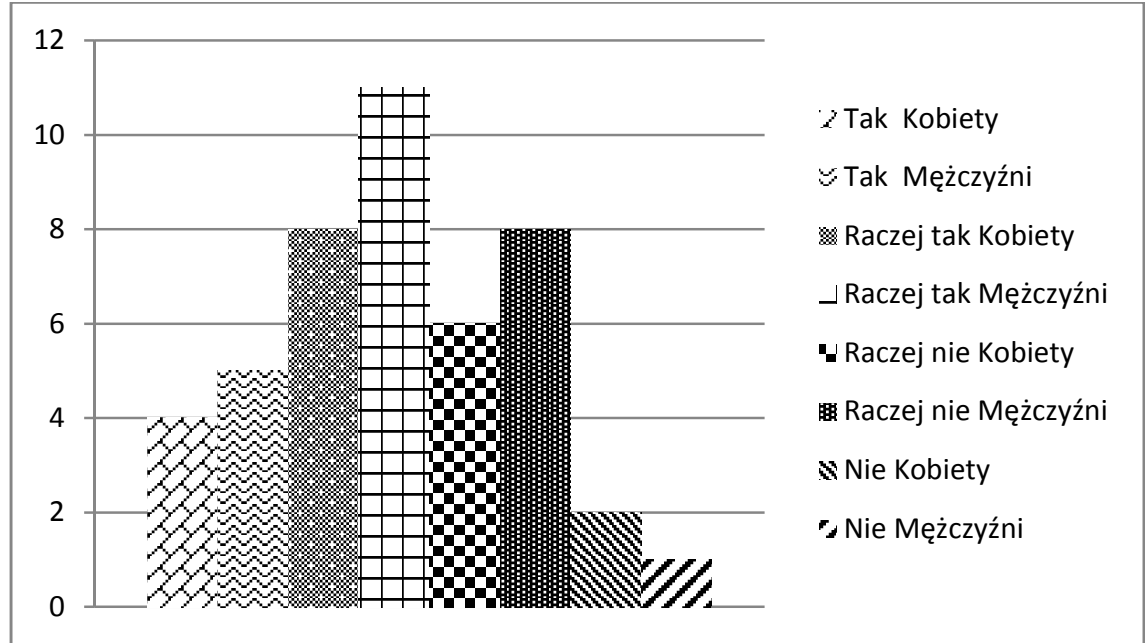

Wykres 6. Porównanie odpowiedzi kobiet i mężczyzn na pytanie: „Czy Konstytucja ma w swojej treści artykuł: „,bezpieczeństwo ekologiczne”?

Źródło: badania własne.

W grupie odpowiedzi - ,tak” odnotowano 4 kobiety i 5 mężczyzn. W grupie odpowiedzi - „nie” odnotowano 2 respondentki i 1 badanego. Wśród ankietowanych nie do końca zdecydowanych (kategoria odpowiedzi: „raczej tak”) największą grupę stanowili mężczyźni (11 osób), dla których w ustawie konstytucyjnej jest artykuł, w którym jest 
mowa o bezpieczeństwie ekologicznym. Wśród kobiet autorzy odnotowali 8 takich ankietowanych. Kategorię odpowiedzi ,raczej nie” wybrało odpowiednio: 6 respondentek i 8 respondentów.

Podsumowując wyniki zobrazowane na wykresie 5 można powiedzieć, że zdecydowana większość kobiet i mężczyzn opowiedziała się za obecnością w Konstytucji artykułu o ochronie środowiska. Natomiast jeśli chodzi o obecność w Konstytucji artykułu na temat bezpieczeństwa ekologicznego (wykres 6), to zdecydowanie większa część mężczyzn i nieznacznie mniejsza część kobiet, stosując postawę asekuracyjną zaznaczyli odpowiedzi raczej tak i raczej nie.

Uzyskane wyniki badań świadczą o raczej niskim poziomie świadomości respondentów na analizowany temat.

\section{ZAMIAST ZAKOŃCZENIA}

Przyszło żyć nam w ciekawych czasach. Ze świata wytwarzanych informacji opisanych przedrostkiem giga, tera, eksa i więcej docierają do nas jej liczne fragmenty, często wzajemnie sprzeczne. Również z ekologii (gr. oíkos + lógos = dom + nauka), która bada i analizuje zależności w świecie przyrody.

Ważną kwestią jest poznanie błędów, które popełniamy w wyciąganiu wniosków o świecie, aby nie podejmować decyzji automatycznie. Niestety, bardzo często nasze decyzje podyktowane są heurystykami.

Heurystyki funkcjonują w naszym umyśle jak zautomatyzowane procesy przy pomocy, których szybko wydajemy sądy. Jak każdy automatyzm, również i ten ma swoje wady, które mogą wpływać na powstawanie nieporozumień a nawet poważnych problemów ${ }^{18}$. Są to schematy, którymi posługują się ludzie, aby jak uważają, efektywnie wypowiadać się o sytuacjach społecznych.

Autorzy zdają sobie sprawę, że przedstawiony problem jest bardzo złożony i wymaga dalszych interdyscyplinarnych badań. Na dzień dzisiejszy nie można postawić jednoznacznych wniosków. Autorzy studiując literaturę przedmiotu słuchając animatorów środowiska pragną zakończyć artykuł definicją Btędu potwierdzenia (ang. confirmation bias). Efekt potwierdzenia, nazywany także błędem konfirmacji, jest bardzo silnym mechanizmem kognitywnym, którego zadaniem jest chronienie nas przed emocjonalnym dyskomfortem, który odczuwamy, gdy w obliczu niepodważalnych dowodów zmuszeni jesteśmy zmienić swoje poglądy, do których zdążyliśmy się emocjonalnie przywiązać ${ }^{19}$.

W obiegu społecznym mocno zakorzenione jest pojęcie bezpieczna ekologiczna żywność wysokiej jakości. Autorzy nie zapytają przeciętnych państwa Nowaków jaką ona jest? Prawdopodobieństwo otrzymania prawidłowej odpowiedzi będzie porównywalne z przeprowadzonymi badaniami. Zaproponują natomiast aby prześledzili drogę wybranego produktu mając w pamięci słowo: bezpieczny 1.»taki, któremu nic nie grozi« 2. »niczym niezagrażający, chroniący przed niebezpieczeństwem $\ll^{20}$.

${ }^{18}$ HEURYSTYKI - czyli o tym dlaczego tak tatwo wpadamy w pułapki..., konradszczypczyk. pl/heurystyki-czyli-o-tym-dlaczego-tak-latwo-wpada... (dostęp: 21.11.2016 r.).

19 Efekt potwierdzenia w praktyce | Forex, fundusze, inwestowanie, gra..., https://blogi.bossa.pl > Trystero (dostęp: 21.11.2016 r.).

${ }^{20} \mathrm{http} / / /$ sjp.pwn.pl/sjp/bezpieczny (dostęp: 20.12.2016 r.). 
Np. wyroby mięsne są objęte stałym państwowym nadzorem weterynaryjnym, realizowanym przez Główny Inspektorat Weterynaryjny z oddziałami terenowymi na etapie hodowli, transportu do ubojni i w rzeźni/masarni w procesie przetwórstwa: przetworzone, częściowo przetworzone lub nieprzetworzone. Zanim trafią do klienta przez sieć hurtowni i ladę sklepową są przemieszczane zgodnie z normami: polską, branżową i zakładową, monitorują je między innymi służby Państwowej Inspekcji Sanitarnej, Instytut Żywności i Żywienia.

Daje się zauważyć we współczesnym społeczeństwie trend, że mamy w zwyczaju słuchać informacji, które potwierdzają nasze wstępne doświadczenia. Jest to jedna z przyczyn, dla której tak trudno jest prowadzić inteligentną rozmowę na „wysokim” poziomie, na temat ekologii. Po części wyjaśnia to, dlaczego niektórzy czytają wątpliwej jakości źródła tylko po to, aby treść zgadzała się z ich pojmowaniem świata.

Absolwent filologii do niedawna skazany był na pracę nauczyciela. O pracy w biznesie mógł tylko pomarzyć. Doczekaliśmy czasów, że łatwiej jest nauczyć absolwenta filologii bezpieczeństwa. A eksperci od szerokiego bezpieczeństwa powinni perfekcyjnie porozumieć się ze swoimi rozmówcami. Filologu powiedz: non possummus, czyli nie mogę kroku dalej, bo swoją wiarygodnością będę..... - apelują autorzy.

\section{LITERATURA}

[1] Bezpieczeństwo: istota, podstawowe kategorie i historyczna ewolucja, https://www. bbn.gov.pl/.../Bezpieczenstwoistotapodstawowekategorieihistorycznaewol...

[2] Efekt potwierdzenia w praktyce. Forex, fundusze, inwestowanie, gra..., https://blogi. bossa.pl > Trystero

[3] HEURYSTYKI - czyli o tym dlaczego tak łatwo wpadamy w pułapki..., konradszczypczyk.pl/heurystyki-czyli-o-tym-dlaczego-tak-latwo-wpada...

[4] http://wol.jw.org/pl/wol/d/r12/lp-p/2014642\#h=2]

[5] http://www.biotechnolog.pl/gmo

[6] ttp://bazhum.muzhp.pl/media//files/Studia_Philosophiae_Christianae/Studia_ Philosophiae_Christianae-r2000-t36-n2/Studia_Philosophiae_Christianae-r2000-t36-n2s67-79/Studia_Philosophiae_Christianae-r2000-t36-n2-s67-79.pdf

[7] http://bip.kozienice.pl/dokument-2152-strategia_bezpieczenstwa_narodowego.html

[8] http://www.msz.gov.pl/resource/7d18e04d-8f23-4128-84b9-4f426346a112

[9] http://seib.uksw.edu.pl/sites/default/files/tom_10_1_2_mariusz_ciszek_bezpieczenstwo_ ekologiczne_i_zrownowazony_rozw\%C3\%B3j_w_aspekcie_strategii_bezpieczenstwa_ narodowego.pdf

[10] http://wyborcza.pl/1,75400,20620239,poczatek-antropocenu-po-smieciach-nas-poznacie. html

[11] http://sjp.pwn.pl/sjp/bezpieczny

[12] https://www.bbn.gov.pl/ftp/SBN\%20RP.pdf

[13] Konstytucja RP. Tekst uchwalony w dniu kwietnia 1997r. przez Zgromadzenie Narodowe (Dz.U. z 1997 r., nr 78, poz. 483).

[14] Majer P., W poszukiwaniu uniwersalnej definicji bezpieczeństwa wewnętrznego, „Przegląd Bezpieczeństwa Wewnętrznego" 7/12, cejsh.icm.edu.pl/cejsh/element/bwmeta1. element...8840.../PBW_nr_7.11-19.pdf

[15] Pojęcie bezpieczeństwa - Geopolityka.net - polski portal o geopolityce..., geopolityka. net/pojecie-bezpieczenstwa/ 
[16] Założenia polityki bezpieczeństwa i strategia obronna..., koziej.pl/wp-content/uploads/ 2015/07/Strategia_RP_z_92_r.doc

\section{UNDERSTANDING OF VOCABULARY USED IN PROTECTION AND DEVELOPMENT OF HUMAN ENVIRONMENT IN STATE DOCUMENTS}

This article is a continuation of the discussion, which we indicated in the article "Guidelines for environmental education and ecological safety" published in the quarterly Humanities and Social Science.

The authors examine different ways of understanding of vocabulary and concepts related to the protection and shaping of human environment in the state documents based on the example of the national security strategy of: 2003, 2007 and 2014.

Nowadays representatives of various fields of science, both theorists and practitioners, dispute on the topics and issues related to the widely understood "ecology". What is obvious for some researchers, to others is room for controversy. The authors point out that today the strongest source of non-formal education is the media.

Unfortunately we cannot give a positive statement after the survey, which aim was to find out the level of differentiation of words and concepts used in formal documents. Diagnostic survey with a questionnaire has been used as a test method. The knowledge level of respondents is far too small. The change of environmental attitudes occurring during their livetime is an important issue here. Did they participate in it and did they notice this change? The answers to these questions are not always simple and straightforward and they require further and targeted studies on other respondents' groups.

The article points out the meaning of education in attitude shaping process and its necessity in the modern world due to the increasing and negative impact of anthroposphere on the natural environment.

Keywords: constitution, the strategy of national security, environmental protection, ecological safety, sozology, anthropopressure.

DOI: 10.7862/rz.2017.hss.76

Przestano do redakcji: styczeń $2017 r$.

Przyjęto do druku: grudzień 2017 r. 